\title{
Influenza and SARS-CoV-2 coinfection during the COVID-19 pandemic
}

\section{COVID-19 pandemisinde SARS-CoV-2 ve İnfluenza koinfeksiyonu}

\author{
Mehmet Sami isLAMOĞLU1 (ID), Betül BORKU UYSAL ${ }^{1}$ (ID)
}

\begin{abstract}
Objective: Because severe acute respiratory syndrome coronavirus 2 (SARS-CoV-2), which produces pandemic pneumonia and has a more fatal course than seasonal flu, has no effective treatment, protection against secondary infections is essential in preventing disease-related mortality. The study's goal is to prove a link between seasonal Influenza A-B and SARS-CoV-2 coinfections in the winter, when respiratory tract illnesses are widespread.
\end{abstract}

Methods: This study was designed retrospective. After ethic commitee approval; 515 patients with cold symptoms between November 2, 2020 and February 17, 2021 were included in study. Influenza Antigen Card Plus was used for the detection of influenza. In the PCR test for SARS-CoV-2, swab samples taken from both the mouth and nose were studied in the CFX96 Real time PCR device. Patients were divided into groups according to whether the Influenza A-B and COVID-19 PCR tests were positive or negative. The relationship between influenza A-B positivity and SARS-CoV-2 positivity was investigated.

Results: The female / male ratio in the 515 patients included in the research was $60.7 \%$ / 39.2\%. Influenza positivity was found $55.2 \%$ in women and $44.5 \%$ in men. Influenza-A was revealed to be the most prevalent influenza subtype. Influenza and COVID-19 coinfection was detected in $33.1 \%$ of the cases. Influenza-A was

\section{ÖZET}

Amaç: Pandemik pnömoniye neden olarak tüm dünyada hızla yayılan ve mevsimsel gribe göre daha mortal seyreden Severe Acute Respiratory Syndrome Coronavirus-2 (SARS-CoV-2)'nin etkin bir tedavisi olmadığından hastalığa bağlı ölümlerde sekonder enfeksiyonlardan korunma önemlidir. Çalıșmanın amacı, solunum yolu enfeksiyonlarının sık görüldüğü kıș sezonunda mevsimsel İnfluenza A-B ve SARS-CoV-2'nin birlikte olduğu ko-infeksiyonun gösterilmesidir.

Yöntem: Çalışma retrospektif olarak planlandı. Etik kurul onayının alınmasının ardından 2 Kasım 2020 ile 17 Şubat 2021 arasında soğuk algınlığı semptomları ile başvurmuş olan 515 hasta çalıșmaya alındı. İnfluenza tespiti için İnfluenza Antijen Card Plus yöntemi kullanıldı. SARS-CoV-2'nin PCR yöntemi ile tespiti için ağız boșluğu ve burundan alınan sürüntü örnekleri CFX96 Real time PCR cihazında çalıșıldı. Hastalar İnfluenza $A-B$ ve Reverse transcription polymerase chain reaction COVID-19 RT-PCR pozitif veya negatif olmasına göre gruplara ayrıldı. Hastalarda İnfluenza A-B pozitifliği ile SARS-CoV-2 pozitif vakaların birlikteliğine bakıldı.

Bulgular: Çalışmaya alınan 515 hastada kadın / erkek oranı \%60.7 / \%39.2 saptandı. İnfluenza pozitifliği kadınlarda $\% 55.2$, erkeklerde $\% 44.5$ saptandı ve COVID-19 ko-infeksiyonu \%33,1 vakada saptandı. COVID-19 RT-PCR testi pozitif olan 177 hastanın \%29,9 (53)'unda İnfluenza-A, \%10.1 (18)'inde İnfluenza-B

'Biruni University, Medical Faculty, Department of Internal Medicine, İstanbul

İletişim / Corresponding Author : Mehmet Sami İSLAMOĞLU Beşyol, Eski Londra Asfaltı No:10 Küçükçekmece / İstanbul - Türkiye E-posta / E-mail : mislamoglu@biruni.edu.tr

DOI ID : 10.5505/TurkHijyen.2021.92489

İslamoğlu MS, Borku Uysal B.Influenza and SARS-CoV-2 coinfection during the COVID-19 pandemic.

Turk Hij Den Biyol Derg, 2021; 78(3): 373 - 378 
positive in $29.9 \%$ and Influenza B was positive in $\% 10.1$ of the patients with positive COVID-19 RT-PCR test.

Conclusion: We have determined that it can be seen as a coinfection with SARS-CoV-2, as well as the occurrence of Influenza alone during the flu season. Although the pandemic appears to be speeding up at times owing to changes in isolation measures, the impact of influenza, other respiratory tract diseases, and coinfection on the disease's progression is unknown, and further study is needed.

Key Words: SARS-CoV-2, Influenza, coinfection, flu season pozitif saptandl.

Sonuç: Grip sezonunda tek bașına İnfluenza görülmesinin yanında, SARS-CoV-2 ile koinfeksiyon olarak da görülebildiği ortaya konuldu. İzolasyon önlemlerindeki değişimlere bağlı olarak pandeminin aralıklı olarak hızlandığı görülmekle birlikte influenzanın, diğer solunum yolu infeksiyonlarının ve koinfeksiyonun hastalık seyrine etkisi net olmayıp bu konuda ileri araștırmalara gereksinim vardır.

Anahtar Kelimeler: SARS-CoV-2, İnfluenza, koinfeksiyon, grip sezonu

\section{INTRODUCTION}

Coronavirus disease-2019 (COVID-19) spread rapidly after being identified as cases of pneumonia of unknown etiology in Wuhan, China on December $19^{\text {th }}$ 2019, and was recognized as a pandemic by the World Health Organization in March 2020. In many countries, the health-care system was overburdened (1). It was predicted that SARS-CoV-2, which spread all over the world in March 2020, towards the end of the flu season, would increase the burden on the health system in the autumn-winter period of 2021 due to its longer-term association with influenza. (2). The coexistence of influenza and COVID-19 during influenza season, as expected, made COVID-19 diagnosis and treatment complicated (2).

Influenza is most common in the winter, and the severity of the disease varies depending on the vaccine's efficacy, the nature of the circulating virus, and the length of the season (3). Symptoms described in COVID-19, such as headache, fever, malaise, and a runny nose, are also present in influenza and other severe respiratory infections (3-4). Atypical symptoms associated with COVID-19, such as nausea, vomiting, and diarrhea, can also be observed with influenza (5).
The World Health Organization reported the annual incidence of death due to seasonal influenza as 650 thousand (6). Between October 2019 and April 2020, the United States of America Disease Control and Prevention Center estimated that influenza caused 30-56 million patients, 410-740 thousand hospitalizations, and 24-62 thousand deaths (7). Human-to-human transmission of SARS-CoV-2 is 3.6 times more than that of influenza, the population is more vulnerable to SARS-CoV-2, and the mortality rate of SARS-CoV-2 is higher (8-9). The epidemiology and course of coinfection is poorly known (2). The frequency of coinfection ranges between $0.5 \%$ and $50 \%$ in studies. Seasonal, vaccination coverage, and geographical variables might all play a role in the variability (2).

The goal of our investigation was to discover influenza and COVID-19 coinfection throughout the flu season.

\section{MATERIAL and METHOD}

The study consists of 605 patients in 4-month period from November $2^{\text {th }}, 2020$ to February $17^{\text {th }}$, 
2021 who had applied to internal medicine outpatient clinics with cold symptoms (sore throat, weakness, fever, runny nose, joint pain, headache). Data of 90 patients could not be accessed. In 515 patients whose data were available, co-existence of positivity in influenza A or B and SARS-CoV-2 were investigated. The patients were divided into groups according to whether the Influenza A-B and COVID-19 PCR tests were positive or negative. Influenza Antigen Card Plus was used for the detection of influenza. Influenza Antigen Card Plus is an in vitro descriptive test based on the immunochromatographic method. This test, which results in eight minutes using nasopharyngeal swab samples of symptomatic patients, was developed to qualitatively detect influenza type $A$ and type B. Influenza Antigen Card Plus uses monoclonal antibodies specific for influenza type $A$ and type $B$ antigen for accurate determination of influenza. In the PCR test for coronavirus, swab samples taken from both the mouth and nose were studied in the CFX96 Real time PCR device. In the device, 200 RFU values in each channel were taken as thershold values. HEX channel was studied as an internal control and sigmoidal curves with $\mathrm{Ct}$ value $<=$ 32 in this channel were accepted. Sigmoidal curves with a $\mathrm{Ct}$ value of $<=38$ in the FAM channel were considered positive.

Both authors declare that the study was conducted in accordance with the World Medical Association Helsinki "Ethical Principles for Medical Research Containing Human Subjects". This study was approved by an Ethics Committee of Biruni University and numbered as 2015KAEK-50-21-07.

The compliance of all data to normal distribution was analyzed using the Kolmogorov - Smirnov test. Categorical variables are presented as percentages, while continuous variables are presented as mean \pm standard deviation. Categorical variables were analyzed with the chi-square test, while continuous variables were analyzed in two-way groups with the t test. All data were tested using SPSS 20.0 (SPSS, Chicago, IL, USA) software and $p<0.05$ values were considered statistically significant.

\section{RESULTS}

The female / male ratio in the 515 patients included in the research was 313/202. Influenza positivity was found $55.2 \%$ in women and $44.5 \%$ in men. In influenza negative patients, the mean age was $33.1 \pm 15.7$. The mean age of influenza positive patients was $31.14 \pm 13.40$ and similar. Dyspnea, taste and smell abnormalities, and diarrhea were significantly more common in influenza positive patients. Influenza and COVID-19 coinfection was detected in $33.1 \%(n=87)$ of the cases (Table-1).

Table 1. Demographic and clinical characteristics of Influenza positive and negative patients

\begin{tabular}{|c|c|c|c|}
\hline & Influenza Positive $(\mathbf{n = 2 6 3 )}$ & Influenza Negative $(\mathbf{n = 2 5 2})$ & $\mathbf{p}$ \\
\hline Age & $31.14 \pm 13.40$ & $33.10 \pm 15.10$ & 0.827 \\
\hline Gender (Female) & $173(55.2)$ & $140(44.7)$ & 0,971 \\
\hline Fever & $133(50.6)$ & $148(59)$ & 0.224 \\
\hline Cough & $161(61.5)$ & $148(59)$ & 0.823 \\
\hline Fatigue & $228(87.9)$ & $195(77.7)$ & 0.080 \\
\hline Dyspnea & $163(62.3)$ & $42(16.7)$ & $<0.001$ \\
\hline Taste/smell abnormalities & $52(19.7)$ & $21(8.3)$ & 0.011 \\
\hline Diarrhea & $16(6.3)$ & $16(6.6)$ & 0.562 \\
\hline Chest pain & $129(49.2)$ & $69(27.3)$ & 0.001 \\
\hline Coronavirus PCR positivity & $87(33.1)$ & $90(35.7)$ & 0.578 \\
\hline
\end{tabular}


According to influenza subtypes, the most common types are Influenza-A 62.7\%; Influenza B 17.1\%; Influenza A-B was found to be $20.1 \%$. In 87 coronavirus PCR positive patients, the most common types of influenza in the form of coinfection were Influenza $A$ 53; Influenza B 18; Influenza A-B was determined as 16 (Table 2). When the distribution of influenza and
SARS-CoV-2 co-infection was examined by months and weeks throughout the flu season between November and February, November was the month with the highest prevalence of SARS-CoV-2 and influenza coinfection. Despite the fact that coinfection reduced in December and January, it increased in the first 15 days of February (Table3).

Table 2. Coronavirus positivity and Influenza subtype positivity

\begin{tabular}{|c|c|c|c|}
\hline & \multicolumn{3}{|c|}{ SARS-CoV-2 PCR } \\
\hline & PCR Positive $(\mathrm{n}=87)$ & PCR Negative $(\mathrm{n}=176)$ & $\mathrm{P}$ \\
\hline Influenza Type A & $53(20.1)$ & $112(42.5)$ & 0.537 \\
\hline Influenza Type B & $18(6.8)$ & $27(10.2)$ & \\
\hline Influenza Type A-B & $16(6.0)$ & $37(14.0)$ & \\
\hline
\end{tabular}

Table 3. Evaluation of infectivity by months and weeks during the flu season

\begin{tabular}{|c|c|c|c|c|c|}
\hline Month & $\begin{array}{l}\text { Total sample number } \\
\qquad(n=515)\end{array}$ & $\mathrm{n}$ & $\begin{array}{c}\text { SARS-CoV-2 PCR } \\
\text { Positive and Influenza } \\
\text { Positive }(n=87)\end{array}$ & $\begin{array}{l}\text { SARS-CoV-2 } \\
\text { positive } \\
(n=177)\end{array}$ & $\begin{array}{c}\text { Influenza } \\
\text { Positive } \\
(n=263)\end{array}$ \\
\hline \multirow{4}{*}{ November } & 2-8 November & 66 & 15 & 28 & 35 \\
\hline & 9-15 November & 59 & 14 & 29 & 29 \\
\hline & 16-22 November & 49 & 6 & 19 & 22 \\
\hline & 23-30 November & 55 & 13 & 23 & 26 \\
\hline \multirow{4}{*}{ December } & 1-7 December & 25 & 3 & 10 & 6 \\
\hline & 8-14 December & 23 & 6 & 8 & 11 \\
\hline & 15-22 December & 23 & 3 & 10 & 10 \\
\hline & 23-31 December & 30 & 5 & 9 & 17 \\
\hline \multirow{4}{*}{ January } & 1-8 January & 24 & 3 & 6 & 18 \\
\hline & 9-16 January & 23 & 4 & 5 & 13 \\
\hline & 17-24 January & 18 & 0 & 1 & 12 \\
\hline & 25-31 January & 24 & 4 & 9 & 13 \\
\hline \multirow[b]{2}{*}{ February } & 1-7 February & 34 & 6 & 7 & 23 \\
\hline & 8-17 February & 62 & 5 & 13 & 28 \\
\hline \multicolumn{3}{|c|}{$\mathrm{p}$} & 0.271 & 0.009 & 0.058 \\
\hline
\end{tabular}

\section{DISCUSSION and CONCLUSION}

In our study, influenza and SARS-CoV-2 positivity in the form of coinfection was $33.1 \%$, and the most common coinfection associated with coinfection was
influenza-A. COVID-19 is thought to have originated in a food market where wild animals are sold, and an intermediate host has not yet been identified by genomic sequencing (10-11). It can be transmitted via contaminated hands, surfaces and aerosol droplets 
from human to human (12). The average incubation period is 5 days and may extend up to 2 weeks (13). If COVID-19 is in the form of an influenza or any other agent coinfection, it can be difficult to distinguish symptoms. Influenza differs from COVID-19 because it takes 5-10 days to spread, patients are generally in mild to moderate clinical condition, mortality is less than $1 \%$, acute respiratory distress syndrome is rare, and antiviral therapy is available (3). The frequency of coinfection in patients with COVID-19 is up to $50 \%$ in studies, and the most common pathogens are Streptococcus pneumonia, Staphylococcus aureus, Klebsiella pneumoniae, Mycoplasma pneumoniae, Chlamydia pneumonia, Legionella pneumophila and Acinetobacter baumannii; Candida species and Aspergillus flavus; Influenza, coronavirus, rhinovirus / enterovirus, parainfluenza, metapneumovirus, influenza $B$ virus, and human immunodeficiency virus are the leading ones (14). In the study conducted by Lai and friends., the most common viral pathogens in the metanalysis of 8 studies were rhinovirus / enterovirus and influenza $\mathrm{A}$, as well as coronavirus, respiratory syncytial virus, parainfluenza, metapneumovirus, and influenza B virus coinfection (14). In this study, in influenza-A cases, COVID-19 caused false negativity in the RT-PCR test and the patients were later found to be positive for the COVID-19 RT-PCR test. Zhu et al. showed the most frequent bacterial coinfections in their study on 257 COVID-19 patients and they were mostly detected in the first 4 days of the disease (15). In their study conducted in Northern California, Kim and friends found $9.5 \%$ SARS-CoV- 2 positivity and $26.7 \%$ non-SARS-CoV-2 pathogens in 1217 samples. They reported the most common coinfection as rhinovirus / enterovirus $(6.9 \%)$, respiratory syncytial virus (5.2\%), and non-SARS-CoV-2 coronaviridae (4.3\%) in those who were positive for SARS-CoV-2(16).

Influenza and COVID-19 coinfection was detected in $33.1 \%$ of the cases (87 cases). The detection of $29.9 \%$ influenza-A and $49.1 \%$ influenza in patients with positive COVID-19 PCR test suggests possible false positivity between tests. Cheng et al.detected SARSCoV-2 and influenza together in 97 patients and SARSCoV-2 alone in 116 patients among 213 patients they retrospectively screened in Wuhan between January
2020 and March 2020. They found no difference in disease severity between the group with coinfection and the group with only SARS-CoV-2. They found higher cytokine levels in patients with SARS-CoV-2, and observed that cytokine storm decreased in patients with coinfection (2). They did not determine the relationship between coinfection with age and gender. In the study conducted by Hernandez and friends, vaccination rate against influenza over 65 years of age in every region in Italy and deaths related to COVID-19 in the region were compared. They found low mortality rates due to COVID-19 in regions with strong negative correlation and high vaccination rate (17). This may be related to the vaccine's rapid local immune response when another pathogen such as SARS-CoV-2 enters by providing sufficient immune memory (17). When the distribution of coinfection cases was investigated by months and weeks in our study, it was discovered that influenza increased in conjunction with the acceleration of the pandemic and the dissemination of SARS-CoV-2. During the pandemic, it was observed that influenza also decreased during the period when the number of cases decreased due to measures such as masks and distance. The precautions taken against SARS-CoV-2 can also be considered as protective against other upper respiratory tract infections.

The most important limitation in the study was that only the influenza panel was examined, but not a large panel covering other viral infections. Secondly, the study cannot be generalized to the whole society, since symptomatic patients who applied to the hospital were included and asymptomatic patients were not in the study. The third limitation was that patients cannot be compared according to their clinics. Finally, since the average age of the study was low and it did not include the elderly and groups with comorbid diseases, further studies are needed in this group.

In conclusion, due to the similarity of symptoms and the margin of error in diagnostic testing, coinfection should not be overlooked in patients diagnosed with influenza and COVID-19 during the influenza season. For a sufficient immunological response, community vaccination for influenza and COVID-19 should be expanded, and when coinfection is confirmed, appropriate antimicrobial therapy should be administered. 


\section{ETHICS COMITTEE APPROVAL}

* The study was approved by the Biruni University Ethics Committee (Date: : 09.06.2021 and Number: 2015KAEK-50-21-07 ).

\section{CONFLICT OF INTEREST}

The authors declare no conflict of interest.

\section{REFERENCES}

1. Maltezou HC, Theodoridou K, Poland G. Influenza immunization and COVID-19. Vaccine. 2020;38(39):6078-9.

2. Cheng $Y$, Ma J, Wang $H$, Wang $X$, Hu Z, Li H,et al. Co-infection of influenza $A$ virus and SARSCoV-2: A retrospective cohort study. J Med Virol. 2021;93(5):2947-954.

3. Konala VM, Adapa S, Gayam V, Naramala S, Daggubati SR, Kammari CB, et al. Co-infection with Influenza A and COVID-19. Eur J Case Rep Intern Med. 2020;7:001656.

4. Cox MJ, Loman N, Bogaert D, O’Grady J. Coinfections: potentially lethal and unexplored in COVID-19. Lancet Microbe. 2020;1.

5. Balla M, Merugu GP, Patel M, Koduri NM, Gayam V, Adapa S, et al. COVID-19, Modern Pandemic: A Systematic Review From Front-Line Health Care Providers' Perspective. J Clin Med Res. 2020;12(4):215-29.

6. Iuliano $A D$, Roguski KM, Chang $\mathrm{HH}$, Muscatello DJ, Palekar R, Tempia S. Estimates of global seasonal influenza-associated respiratory mortality: a modeling study. Lancet. 2018;391:1285-300.

7. Centers for Disease Control and Prevention. 2019-2020 U.S. flu season: preliminary burden estimates. 2020. https://www.cdc.gov/flu/about/ burden/preliminary-in-season-estimates.htm.

8. Distante C, Piscitelli P, Miani A. Covid-19 outbreak progression in Italian regions: approaching the peak by the end of March in Northern Italy and first week of April in Southern Italy. Int J Environ Res Public Health. 2020.

9. Faust JS, del Rio C. Assessment of deaths from COVID-19 and from seasonal influenza. JAMA Intern Med. 2020.
10. Peeri NC, Shrestha N, Rahman MS, Zaki R, Tan Z, Bibi S,et al. The SARS, MERS and novel coronavirus (COVID-19) epidemics, the newest and biggest global health threats: what lessons have we learned? Int J Epidemiol. 2020 doi: 10.1093/ije/ dyaa033.

11. The Atlantic News Report from February 24, 2020. Accessed on February25,2020. https://www. theatlantic.com/health/archive/2020/02/covidvaccine $/ 607000 /$.

12. Li Q, Guan X, Wu P, Wang X, Zhou L, Tong $Y$, et al. Early transmission dynamics in Wuhan, China, of novel coronavirus-infected pneumonia. N Engl J Med. 2020;382:1199-207.

13. Chan JF, Yuan S, Kok KH, To KK, Chu H, Yang J, et al. A familial cluster of pneumonia associated with the 2019 novel coronavirus indicating person-to-person transmission: a study of a family cluster. Lancet. 2020;395(10223):514-23.

14. Lai CC, Wang CY, Hsueh PR. Co-infections among patients with COVID-19: The need for combination therapy with non-anti-SARS-CoV-2 agents? J Microbiol Immunol Infect. 2020;53(4):505-12.

15. Zhu X, Ge Y, Wu T, Zhao K, Chen $Y$, Wu B, et al. Co-infection with respiratory pathogens among COVID-2019 cases. Virus Res. 2020;285.

16. Kim D, Quinn J, Pinsky B, Shah NH, Brown I. Rates of Co-infection Between SARS-CoV-2 and Other Respiratory Pathogens. JAMA. 2020;323(20):2085-6.

17. Marín-Hernández D, Schwartz RE, Nixon DF. Epidemiological evidence for association between higher influenza vaccine uptake in the elderly and lower COVID-19 deaths in Italy. J Med Virol. 2021;93(1):64-5. 